\title{
FOSSILS OF TITANOSAURS (DINOSAURIA, SAUROPODA) FROM A NEW OUTCROP IN TRIÂNGULO MINEIRO, SOUTHEASTERN BRAZIL
}

\author{
RENATO PEREIRALOPES \\ Seção de Paleontologia, Museu de Ciências Naturais, Fundação Zoobotânica do Rio Grande do Sul, Salvador França, \\ 1427,90690-000, Porto Alegre, RS, Brazil.paleonto_furg@yahoo.com.br \\ FRANCISCO SEKIGUCHI DE CARVALHO BUCHMANN \\ Universidade Estadual Paulista, Campus do Litoral Paulista, Campus São Vicente,11.330-900, São Vicente, SP, Brazil. \\ buchmann@csv.unesp.br
}

\begin{abstract}
The Triângulo Mineiro area, in southwestern Minas Gerais State, southeastern Brazil, has been known for decades for its vertebrate fossils, mostly of dinosaurs. Described here are fossils of sauropod dinosaurs from a new fossiliferous outcrop in the region, correlated with the Echaporã Member (Campanian-Maastrichtian) of the Marília Formation. The fossils are a right tibia, two procoelous vertebral centra and a right coracoid, besides a possible phalange and several unidentified fragments, Although the zygapophyses and neural spines had not been preserved, the procoelous vertebrae show that the fossils belonged to sauropods of the clade Titanosauridae. The best preserved vertebra is heartshaped in cross-section, has its ventral half anteroposteriorly compressed and has pleurocoel-like depressions on its lateral cranial portion, features that indicate affinity with the genus Aeolosaurus.
\end{abstract}

Key words: Aeolosaurus, Titanosauridae, Late Cretaceous, Marília Formation, Triângulo Mineiro.

RESUMO - A área do Triângulo Mineiro, no sudoeste do Estado de Minas Gerais, Brasil, é conhecida há décadas por seus fósseis de vertebrados, principalmente dinossauros. Aqui são descritos fósseis de dinossauros saurópodes provenientes de um novo afloramento fossilífero na região, correlacionado ao Membro Echaporã (Campaniano-Maastrichtiano) da Formação Marília. Os fósseis compreendem uma tíbia direita, duas vértebras procélicas e um coracóide direito, além de uma possível falange além de diversos fragmentos não identificados. Embora as zigapófises e espinhas neurais não tenham sido preservadas, as vértebras procélicas mostram que pertenceram a saurópodes do clado Titanosauria. A vértebra melhor preservada apresenta formato cordiforme em seção transversal, tem a metade ventral comprimida ântero-posteriormente e depressões pleurocélicas nas laterais da sua porção cranial, características que sugerem afinidade com o gênero Aeolosaurus.

Palavras-chave: Aeolosaurus, Titanosauridae, Neocretáceo, Formação Marília, Triângulo Mineiro.

\section{INTRODUCTION}

The Triângulo Mineiro region, in southwestern Minas Gerais State, southeastern Brazil, has been known for decades for its vertebrate fossils, mainly of dinosaurs. These fossils are found in Upper Cretaceous rocks of the Bauru Group, which covers an area of about $370,000 \mathrm{~km}^{2}$, reaches a thickness of around $300 \mathrm{~m}$ and is positioned on top of the basaltic rocks of the Serra Geral Formation. This unit originated by deposition of essentially arenaceous sediments in lacustrine, fluvial and aeolian environments on the crustal depression formed by the isostatic subsidence of the Serra Geral basaltic rocks, after the final break-up of Gondwana (Fernandes \& Coimbra, 2000). In the Triângulo Mineiro, the Bauru Group is divided into the Adamantina, Uberaba and Marília formations, deposited between the Cenomanian and Maastrichtian (Soares et al., 1980; Fernandes \& Coimbra, 1996). The Marília Formation was originally divided into three units: Serra da Galga, Ponte Alta and Echaporã members. Later, Oliveira \& Campos (2003) described a fourth unit, named the Araguari Member, in the northern portion of the Triângulo. The fossils described here were collected in an outcrop located about $5 \mathrm{~km} \mathrm{NE}$ of the city of Veríssimo, $30 \mathrm{~km} \mathrm{~W}$ of Uberaba (Figure 1). The lithologic and geomorphologic features of the outcrop, with several tabular strata capped by carbonatic sandstones interbedded with massive pink sandstones, suggest that it correlates with the Echaporã Member of the Marília Formation (Fernandes \& Coimbra, 2000), a geological unit that is also exposed in the vicinity of Prata, located northwest of the location presented here (Goldberg, 1995; Fernandes, 2004).

The rocks of the Bauru Group constitute the largest Cretaceous continental unit in South America (Bertini et al., 1993). In the eastern portion of the Triângulo Mineiro, mainly in the vicinity of the Peiróplis locality, near Uberaba, fossiliferous outcrops have been known since the 1920s, but only since 1947 have these started to be prospected, with the efforts of Llewellyn Ivor Price (Candeiro, 2005). The paleovertebrate fossils found there include anurans, chelonians, squamata, crocodylians and dinosaurs (Candeiro et al., 2006). The most conspicuous dinosaur fossils are of titanosaurid sauropods (Bertini et al., 1993; Kellner \& Campos, 2000; Santucci \& Bertini, 2001; Almeida et al., 2004; Marinho \& Candeiro, 2005; Kellner et al., 2005; Campos et al., 2005). 


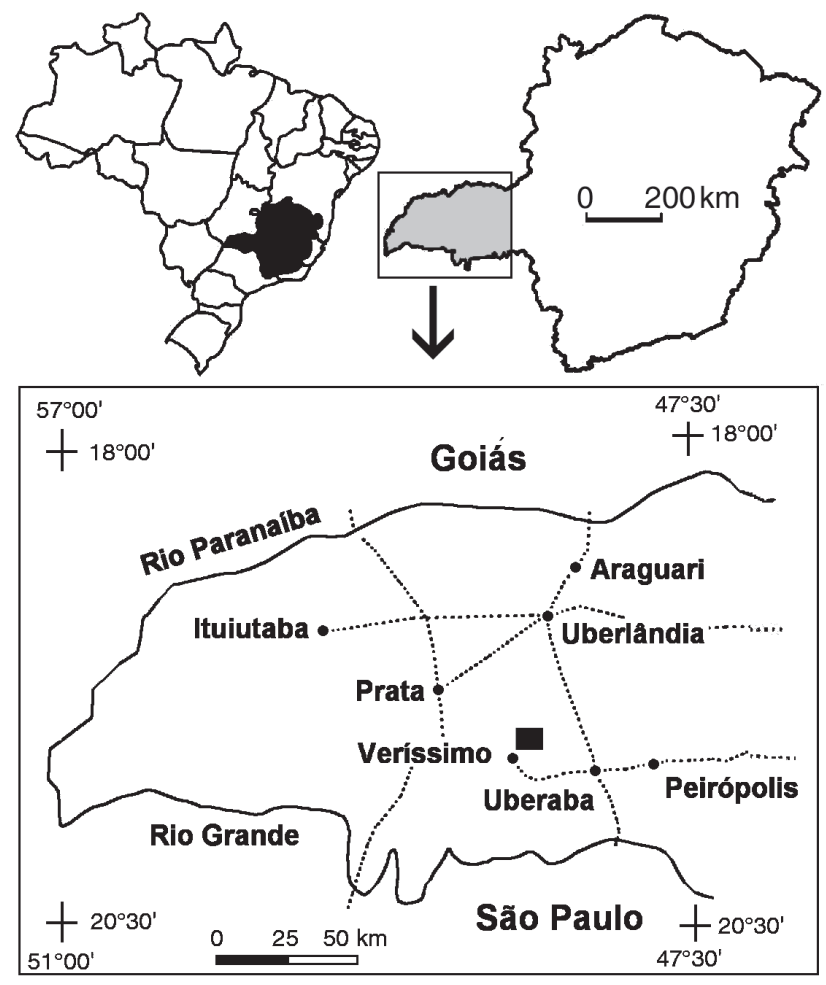

Figure 1. Location map of the new fossiliferous outcrop (black square) in the Triângulo Mineiro.

The fossils described here were collected in a fine to medium pink sandstone layer, exposed on a hill slope due to erosion and removal of vegetation cover (Lopes et al., 2006; Figure 2). The material is now deposited in the paleontological collection of the Laboratório de Geologia e Paleontologia (LGP) of Fundação Universidade Federal do Rio Grande, in Rio Grande. The fossils are a right coracoid, a partial vertebral centrum, a vertebral centrum, a phalanx (?), a left tibia and five unidentified fragments (see Table 1 for measurements). All described specimens were found on the same topographic level, in an area of some $10 \mathrm{~m}^{2}$. The proximity of the remains suggests that they could be from a single individual.

\section{SYSTEMATICS}

\author{
SAUROPODA Marsh, 1878 \\ TITANOSAURIFORMES Salgado et al., 1997 \\ TITANOSAURIA Bonaparte \& Coria, 1993 \\ AEOLOSAURINI Franco-Rosas, 2004 \\ cf. Aeolosaurus sp. Powell, 1987
}

Titanosauria was defined by Salgado et al. (1997) as the clade including the most recent common ancestor of Andesaurus, Malawisaurus, Titanosauridae and all of their descendants. Titanosauridae was defined by these authors as the clade including the most recent common ancestor of Epachthosaurus sciuttoi, Malawisaurus dixeyi, Argentinosaurus huinculensis, Titanosauridae indet. (DGM "Série B"), Opisthocoelicaudia skarzynskii, Aeolosaurus, Alamosaurus sanjuanensis, Saltasaurinae, and all of their descendants. This clade is diagnosed mainly based on the

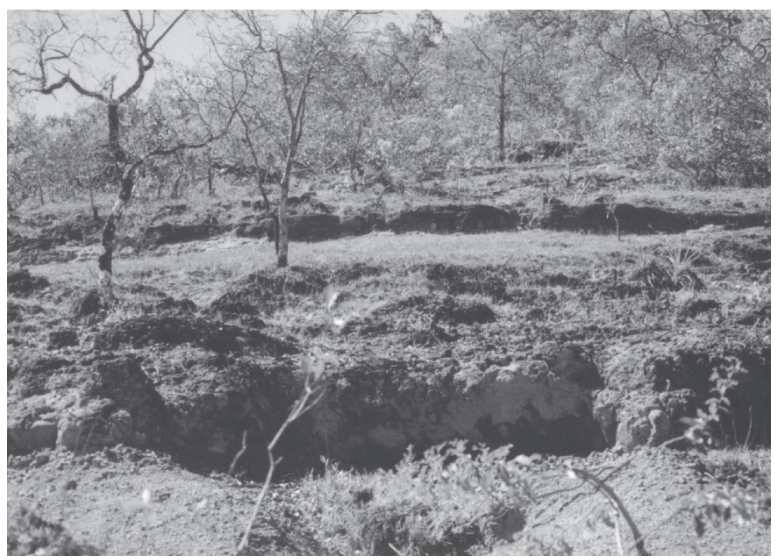

Figure 2. View of the outcrop. The fossils were collected in the lowermost layer.

procoelous caudal vertebrae, and most of the diagnostic features of titanosaurids are based on vertebral morphology (Kellner \& Azevedo, 1999). Wilson and Upchurch (2003) considered invalid the type-species of the genus Titanosaurus and recommended that the genus Titanosaurus and its coordinated rank-taxa (e.g., Titanosaurinae, Titanosauridae, Titanosauroidea) should be abandoned.

\section{Description}

The tibia (LGP-D0005; Figure 3) was found partially exposed, with its lateral surface buried in a fine sandstone layer and oriented in NE-SW direction. A good portion of the bone along its long axis on the lateral surface was eroded and filled with sediment. The medial side exhibits surface crackings and is fragile due to weathering. Both epiphyses were partly eroded, causing the haversian channels to be filled with sediment; thus it was not possible to determine the ontogenetic stage of the animal at the time of death. The cnemial crest was partly preserved, and it forms a concavity on the anterior side of the proximal epiphysis (Figure 3A), which is anteroposteriorly expanded; the distal epiphysis, although badly preserved, is mesiolaterally expanded.

The vertebral centrum LGP-D0002 (Figure 4A) was cracked along its axis; it is lacking any vestiges of neural spines and zigapophyses, which suggest that it is the ventral half of the vertebral body. Although the distal articular surface is poorly preserved, the proximal surface clearly exhibits the characteristic concavity of procoelous vertebrae; the centrum is transversally constricted on its middle portion. These features suggest that it is probably a distal caudal vertebra. The other centrum (LGP-D003, Figure 4B) is almost complete, and although the zygapophyses were not preserved, it appears that they were positioned on the cranial portion of the dorsal surface of the vertebral body. The shape of the centrum indicates that it is an anterior or middle caudal vertebra, with deep pleurocoel-like depressions on both lateral surfaces. The ventral half is laterally compressed, making it narrower than the dorsal half and thus giving the centrum a heart-shaped transverse section. The fossil was subjected to considerable weathering, which, besides destroying the zygapophyses and neural spine, eroded its surface, mainly 


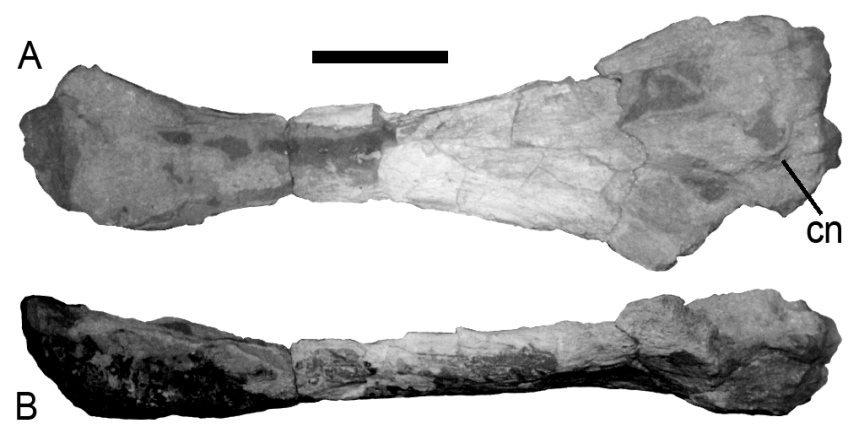

Figure 3.Titanosaur tibia (LGP-D0005), in lateral (A) and cranial (B) views, showing the cnemial crest $(\mathrm{Cn})$. Scale bar $=10 \mathrm{~cm}$.

on the ventral half, and resulted in the haversian channels being filled with sediment.

LGP-D0004 (Figure 4C) is tentatively identified as a phalanx. It is sub-triangular in cross section, and is fragmented along the longitudinal axis, with cavities filled by sediment. LGP-D0001, coracoid (Figure 4D), exhibits a quadrangular shape, because the cranial and dorsal margins meet at an abrupt angle, a characteristic of advanced sauropods (Upchurch, 1998) which is considered a synapomorphy for the advanced titanosaurs (Salgado et al., 1997). This bone is eroded along its margins and its haversian channels are filled with sediment and calcite crystals. The medial surface is concave, while the lateral is convex; the dorsal and cranial margins are thin, in comparison to the thick caudoventral margin. The foramen characteristic of all sauropod coracoids (Upchurch et al., 2004) is not preserved due to breakage of the caudoventral margin. Other fossils are small, unidentified remains (LGP-D0009 to D0010), possibly fragments of neural spines or laterally compressed bones. The fossil LGP-D0009 has the haversian channels preserved, while they are filled with calcite crystals in LGP-D0007.

\section{DISCUSSION}

Although these fossils exhibit significant evidence of post-depositional re-working, its general preservation is similar to fossils from the Marília Formation, as described by Goldberg \& Garcia (2000), with haversian channels filled with
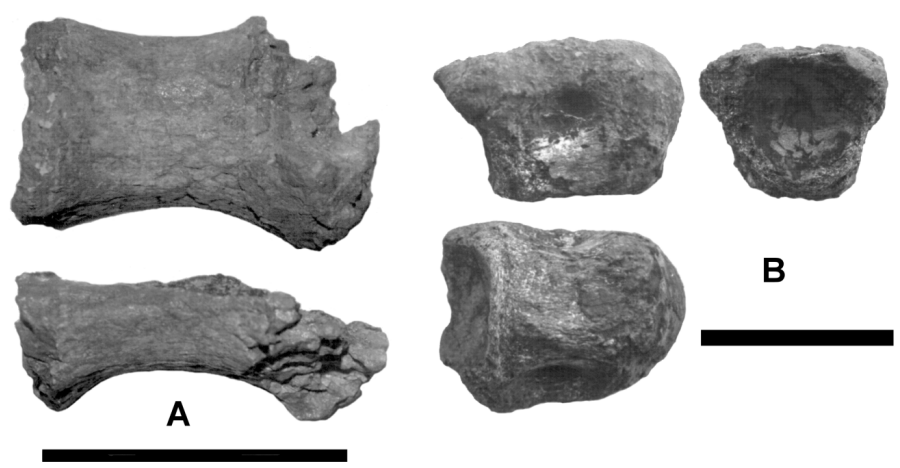

calcite without damage to the bone structure.

Among the fossils, the vertebrae exhibit diagnostic features more clearly. The procoelous feature indicates that they belong to a titanosaur sauropod, according to the Titanosauria synapomorphies (Wilson, 2002). The vertebral centrum LGPD0003 does not have the dorsoventral compression on its middle portion, which is a synapomorphy for Titanosauridae (Upchurch, 1998). This absence though is possibly an artifact of preservation, since the ventral half of this fossil is partially eroded. The heart-shaped transverse section and the anteroposterior compression of this fossil indicate its affinity to the genera Aeolosaurus and Gondwanatitan. On the other hand, this vertebra has pleurocoel-like depressions on its lateral surfaces, like those described in Aeolosaurus rionegrinus, $A$. colhuehuapiensis and Rinconsaurus caudamirus (Calvo \& Riga, 2003; Powell, 2003; Casal et al., 2007), while in the caudal vertebrae of the type specimens of G. faustoi, Trigonosaurus pricei and Baurutitan britoi, this feature is absent (Kellner \& Azevedo, 1999; Campos et al., 2005; Kellner et al., 2005). Furthermore, Santucci \& Bertini (2001) considered Gondwanatitan a junior synonym of Aeolosaurus, and have reported this genus from the Serra da Galga Member of the Marília Formation in the Triângulo Mineiro. Thus, this vertebra is tentatively assigned to Aeolosaurus.

The tibia show similarities to that described in G. faustoi (Kellner \& Azevedo,1999). The proximal portion is anterioposteriorly expanded, while the distal one is transversely expanded. The poor preservation did not allow comparison with the tibia of G. faustoi, where the anterior portion is straighter in comparison to other titanosaurs and is dorsally projected.

Titanosaurids are the most conspicuous dinosaurs of the Bauru Group in the Triângulo Mineiro (Bertini et al., 1993), found in the Uberaba, Adamantina and Marília formations. The remains of titanosaurs found there include eggs, teeth, osteoderms, vertebrae and several skeletal fragments (Kellner $\&$ Campos, 2000). The titanosaur genera include Aeolosaurus, Titanosaurus, Baurutitan and Trigonosaurus. The presence of Aeolosaurus in Serra da Galga Member of the Marília Formation (Santucci \& Bertini, 2001; Candeiro et al., 2007) allows a biostratigraphic correlation with Late Cretaceous (Maastrichtian) Allen, Los Alamitos and Angostura Colorada

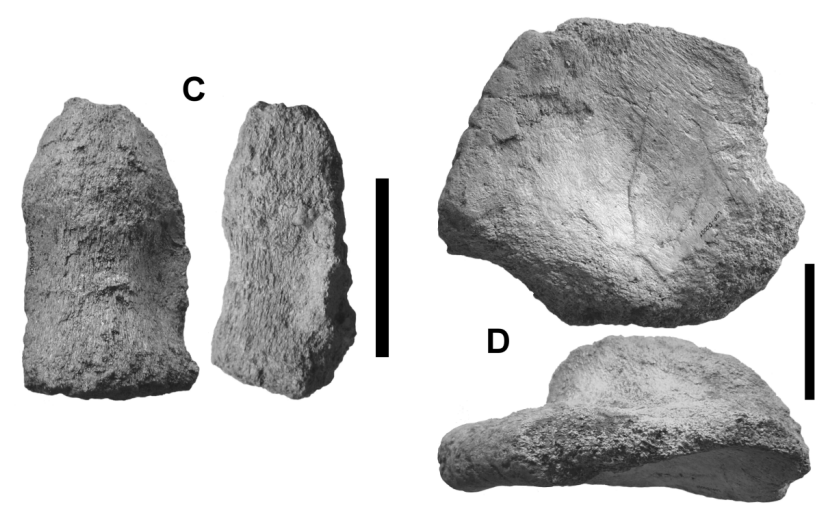

Figure 4. Titanosaurs remains: A, partial caudal vertebral centrum (LGP-D0002); B, caudal vertebral centrum (LGP-D0003); C, possible phalanx (LGP-D0004); D, right coracoid (LGP-D0001) in medial (top) and dorsal (bottom) views. Scale bars $=10 \mathrm{~cm}$. 
Table 1. Fossil measurements $(\mathrm{mm})$. Abbreviations: $M L$, Maximum length; $\mathbf{M H}$, maximum height; $\mathbf{D}$, diameter; PEW, proximal epyphysis maximum width; DEW, distal epyphysis maximum width.

\begin{tabular}{|c|c|c|c|c|c|c|}
\hline Specimen & Identification & ML & MH & D & PEW & DEW \\
\hline LGP-D0001 & coracoid & 242 & 205 & - & - & - \\
\hline LGP-D0002 & \begin{tabular}{|l|} 
distal caudal \\
vertebra
\end{tabular} & 124 & - & 80 & - & - \\
\hline LGP-D0003 & $\begin{array}{l}\text { anterior/middle } \\
\text { caudal vertebra }\end{array}$ & 130 & - & 140 & - & - \\
\hline LGP-D0004 & ?phalanx & 143 & 84 & - & - & - \\
\hline LGP-D0005 & tibia & 560 & - & - & 178 & 110 \\
\hline
\end{tabular}

formations of Argentina (Santucci \& Bertini, 2001). If the correlation of this outcrop with the Echaporã Member of the Marília Formation is confirmed, this will be the first description of titanosaur fossils from this unit in Minas Gerais State, although remains of this taxon have been found in rocks of this same unit in São Paulo State (Bertini et al., 2001).

\section{ACKNOWLEDGMENTS}

The authors thank M. van Tomme (Université Libre de Brussels) for helping with the identification of the fossils; and A. Kellner and an anonymous referee for comments and suggestions.

\section{REFERENCES}

Almeida, E.B.; Ávilla, L.S. \& Candeiro, C.R.A. 2004. Restos caudais de Titanosauridae da Formação Adamantina (TuronianoSantoniano), sítio do Prata, Estado de Minas Gerais, Brasil. Revista Brasileira de Paleontologia, 7(2):239-244.

Bertini, R.J.; Marshall, L.G.; Gayet, M. \& Brito, P. 1993. Vertebrate faunas from the Adamantina and Marília Formations (Upper Bauru Group, Late Cretaceous, Brazil) in their stratigraphic and paleobiogeographic context. Neues Jahrbüch für Geologie und Paläontologie, Abhandlungen, 188(1):71-101.

Bertini, R.J.; Santucci, R.M. \& Arruda-Campos, A.C. 2001. Titanossauros (Sauropoda:Saurischia) no Cretáceo Superior continental (Formação Marília, Membro Echaporã) de Monte Alto, Estado de São Paulo, e correlação com formas associads do triângulo mineiro. Geociências, 20(1):93-103.

Calvo, J.O. \& Riga, B.J.G. 2003. Rinconsaurus caudamirus gen. et sp. nov., a new titanosaurid (Dinosaurua, Sauropoda) from the Late Cretaceous of Patagônia, Argentina. Revista Geológica de Chile, 30(2):333-353.

Campos, D.A.; Kellner, A.W.A.; Bertini, R.J. \& Santucci, R.M. 2005. On a titanosaurid (Dinosauria, Sauropoda) vertebral column from the Bauru Group, Late Cretceous of Brazil. Arquivos do Museu Nacional, 63(3):565-593.

Candeiro, C.R.A. 2005. Geologia e Paleontologia de vertebrados da Formação Marília (Neomaastrichtiano) no sítio paleontológico de Peirópolis. Caminhos de Geografia, 11(16):117-124.

Candeiro, C.R.A.; Martinelli, A.G.; Ávilla, L.S. \& Rich, T.H. 2006. Tetrapods from the Upper Cretaceous (TuronianMaastrichtian) Bauru Group of Brazil: a reappraisal. Cretaceous Research, 27:923-946.

Candeiro, C.R.A.; Santos, A.R.; Bergqvist, L.P.; Ribeiro, L.C.B. \& Apesteguía, S. 2007. The Late Cretaceous fauna and flora of the Uberaba área (Minas Gerais State, Brazil). Journal of South American Earth Sciences, 25:203-216.

Casal, G.; Martinez, R.; Luna, M.; Sciutto, J.C. \& Lamanna, M.C. 2007. Aeolosaurus colhuehuapiensis sp. nov. (Sauropoda, Titanosauria) de la Formación Bajo Barreal, Cretácico Superior de la Argentina. Revista Brasileira de Paleontologia, 10(1):53-62.
Fernandes, L.A. \& Coimbra, A.M. 1996. A Bacia Bauru (Cretáceo Superior, Brasil). Anais da Academia Brasileira de Ciências, 68(2): 195-205.

Fernandes, L.A. \& Coimbra, A.M. 2000. Revisão estratigráfica da parte oriental da Bacia Bauru (Neocretáceo). Revista Brasileira de Geociências, 30(4):717-728.

Fernandes, L.A. 2004. Mapa litoestratigráfico da parte oriental da Bacia Bauru (PR, SP, MG), escala 1:1.000.000. Boletim Paranaense de Geociências, 55:53-66.

Goldberg, K. 1995. Reconstituição paleoambiental do Cretáceo continental na região do Triângulo Mineiro. Universidade do Vale do Rio dos Sinos, Master Thesis, $181 \mathrm{p}$.

Goldberg, K. \& Garcia, A.J.V. 2000. Palaeobiogeography of the Bauru Group, a dinosaur-bearing Cretaceous unit, northeastern Paraná Basin, Brazil. Cretaceous Research, 21:241-254.

Kellner A.W.A. \& Azevedo S.A.K. 1999. A new sauropod dinosaur (Titanosauria) from the Late Cretaceous of Brazil. National Science Museum Monographs, 15:111-142.

Kellner, A.W.A. \& Campos, D.A. 2000. Brief review of dinosaur studies and perspectives in Brazil. Anais da Academia Brasileira de Ciências, 72(4):509-538.

Kellner, A.W.A.; Campos, D.A. \& Trotta, M.N.F. 2005. Description of a titanosaurid caudal series from the Bauru Group, Late Cretaceous of Brazil. Arquivos do Museu Nacional, 63(3):529-564.

Lopes, R.P.; Buchmann, F.S.C. \& Caron, F. 2006. Novo afloramento fossilífero do Cretáceo Superior na região do Triângulo Mineiro, Brasil. In: SIMPÓSIO DO CRETÁCEO DO BRASIL, 7, 2006. Resumos, Serra Negra, UNESP, p. 72.

Marinho, T.S. \& Candeiro, C.R.A. 2005. Titanosaur (Dinosauria: Sauropoda) osteoderms from the Maastrichtian of Uberaba, Minas Gerais State, Brazil. Gondwana Research, 8(4):473-477.

Oliveira, L.A. Campos, J.E.G. 2003. Seqüência conglomerática do Membro Araguari-Grupo Bauru-norte do Triângulo Mineiro. Geociencias, 22(1):43-51.

Powell, J.E. 2003. Revision of South American titanosaurid dinosaurs: palaeobiological, palaeobiogeographical and and phylogenetic aspects. Records of the Queen Victoria Museum, 111:1-173

Salgado, L; Coria R.A \& Calvo, J.O. 1997. Evolution of titanosaurid sauropods. I - Phylogenetic analysis based on postcranial evidence. Ameghiniana, 15(4):3-32.

Santucci, R.M. \& Bertini, R.J. 2001. Distribuição paleogeográfica e biocronológica dos titanossauros (Saurischia: Sauropoda) do Grupo Bauru, Cretáceo Superior do Brasil. Revista Brasileira de Geociências, 31(3):307-314.

Santucci, R.M. \& Bertini, R.J. 2006. A new titanosaur from western São Paulo State, Upper Cretaceous Bauru Group, south-east Brazil. Palaeontology, 49(1):59-66.

Soares, P.C.; Landim, P.M.B.; Fúlfaro, V.J. \& Sobreiro, Neto A.F. 1980. Ensaio de caracterização do Cretáceo no Estado de São Paulo: Grupo Bauru. Revista Brasileira de Geociências, 10(3): 177-185.

Upchurch, P. 1998. The phylogenetic relationships of sauropod dinosaurs. Zoological Journal of the Linnean Society, 124:43-103.

Upchurch, P.; Barrett, P.M. \& Dodson, P. 2004. Sauropoda. In: D.B.Weishampel; P. Dodson \& H. Osmólska (Eds.) The Dinosauria, California University Press, p. 259-322.

Wilson, J.A. 2002. Sauropod dinosaur phylogeny: critique and cladistic analysis. Zoological Journal of the Linnean Society, 136:217-276.

Wilson, J.A. \& Upchurch, P. 2003. A revision of Titanosaurus Lydekker (Dinosauria - Sauropoda), the first dinosaur Genus with a 'gondwanan' distribution. Journal of Systematic Paleontology 3(1): 125-160.

Received in October, 2007; accepted in March 2008. 